\title{
Role of Vaginal Washing in Semen Detection and D.N.A. Profiling in Delayed Medical Examination of Sexual Assault Cases: A Case Study
}

\author{
Naresh $K^{*}$, Ritika G ${ }^{1}$, Aanchal $M^{1}$, Dhruw $S^{1}$, and Shukla $S^{2}$ \\ ${ }^{1}$ Forensic Science Laboratory, Rohini, Govt of NCT of Delhi, India \\ ${ }^{2}$ Professor and Head of Amity Institute of Forensic Science, Amity University, Noida U.P. India
}

*Corresponding author: Naresh K, Forensic Science Laboratory, Rohini, Govt of NCT of Delhi, India, Tel: +919971918173, E-mail: nareshkumar2982@yahoo.com

Citation: Naresh K, Ritika G, Aanchal M, Dhruw S, Shukla S.K(2017) Role of Vaginal Washing in Semen Detection and D.N.A. Profiling in Delayed Medical Examination of Sexual Assault Cases: a Case Study. J Forensic Sci Criminol 5(5): 501

Received Date: June 26, 2017 Accepted Date: November 03, 2017 Published Date: November 06, 2017

\begin{abstract}
Sexual assault is a social problem faced by every society irrespective of caste, creed or culture. In cases of sexual assault, as soon as the victim files the First Information Report (F.I.R.) she gets the medical examination at nearby government hospital by a gynaecologist. But it is seen that due to hesitation, social problems or any kind of relation between the victim and the accused matter is not reported immediately to the police. This hesitation results in the delay of the medical examination and collection of samples like vaginal swabs, breast swabs, nails swab, and other bodily swabs. In such cases, it is noted that the detection of semen and profiling of DNA fails due to daily hygienic chores. In this delayed medical examination case, semen detection and D.N.A. profiling was done on all the exhibits and concluded that where other exhibits like vaginal, and bodily have failed to detect the semen and DNA profiling, while vaginal wash played important role in detection of semen and DNA profiling in the case, even after more then 100 hours of the incident. Vaginal wash is the best source for detection of semen and DNA profiling, especially in the delayed medical examination cases. Differential extraction is the best way to for differentiating the male and female part but should avoid in the case where quantity of sperm is less. Generally the quantity is very less in delayed medical examination cases and should be handled properly as there are chances of the loss of male DNA during differential isolation. In this study, it was found that high amount of female fraction, peaks of male DNA will be very poor and a conclusive report was prepared with the support of Y-STR analysis.
\end{abstract}

Keywords: Semen; Vaginal wash; DNA profiling; Extraction; Female fraction

\section{Introduction}

A sexual offense is such a crime, no eyewitnesses are found there is generally victim and accused, that's why prosecution wants to prosecute the accused on the basis of the physical and biological evidence left at the crime scene spot or the body of the victim. These two types of evidence play the vital role in the reconstruction of an event [1] In sexual assault cases where the quantity of semen is poor then direct acid phosphatase test can help to locate the dilute semen stains [2]. Modern methods of D.N.A. profiling are highly dependable and well grounded upon in forensic biological examination of samples as it can generate confirmatory results for the identity of the person. Epithelial cells also give the profile of the victim along with the profile of perpetrator in particularly in sexual assault cases; however, efforts can be made for differentiating the male part (spermatozoa) from epithelial cells. In such cases, the D.N.A. profile generated from various exhibits taken from the body of the victim collected during the medical examination using SAFE (Sexual Assault Forensic Examination) kit can be easily used to link the accused to the crime. This can be done even for vasectomised or azoospermic individuals using Y-STR examination but no differential extraction. The linking of the accused to the crime can also be done in the case of delayed examination. In my previous study published in 2015 (13) a total of 20 cases were analysed and average value of DNA from the vaginal washing was $16.32 \mathrm{ng} / \mu \mathrm{lout}$ of $20 \mathrm{samples}, 18$ samples showed positive results while remaining 2 samples showed nil concentration while other body swabs were less than vaginal washing. The present study is an attempt to evaluate the positive result in delayed medical examination submission to forensic lab and delayed examination. This is shown in the given case study.

\section{Case Study}

The case involves a minor victim of around 16 years of age who was sexually assaulted by her brother-in-law in an Apartment in 
Delhi on the night of $21^{\text {st }}$ March'14. The accused managed escaping from the site of crime on $22^{\text {nd }}$ March 2014 . The victim managed to get back home after the accused had run away. She did not report the matter to the police due to close relation to the accused and social hesitation. Victim of the sexual assault simply wants to go the safe place where she feels secure, try to clean up and want to forget the tragic incident. [3] Family relationship with accused may delay reporting the case up to one month [4]. She filed the First Information Report (F.I.R.) on the $25^{\text {th }}$ March 2014 and the police officers took her to the nearby government hospital on the same day few hours after reporting the matters to police and her medical examination was done. All the exhibits were collected from the victim's body using the SAFE (Sexual Assault Forensic Examination) kit along with washing from vagina. These samples/ exhibits were sent to the Forensic lab for examination on $4^{\text {th }}$ April 2014 i.e., after 11 days. The delay of 11 days to submit the samples in Forensic Lab was procedural delay as police prepared the charge sheet and other documents. It is clear from the case history that there was a delay of approximately four and a half days in the medical examination from the time of sexual assault of the victim which is very crucial. Clothes like undergarments and bed sheet may help for long duration for semen stains [5]. No bed sheet was collected by the Investigation officer of this case and undergarments were washed prior to the medical examination. The confirmatory test for semen was negative on garments and vaginal swabs etc. The samples were examined in the lab and it was found that the detection of semen and D.N.A. profiling of the accused was successfully developed only from one of the bodily swabs/ samples i.e., vaginal washing, no other sample was positive for semen. Peak size was female fraction was much higher than male part due to small quantity of spermatozoa in mixed profile.

\section{Materials and Methods}

The exhibits of the given case were received in the lab on $4^{\text {th }}$ April, 2014 and were stored at $4{ }^{\circ} \mathrm{C}$ as per standard protocol to ensure diminished levels of degradation. Due to a large number of pending cases in the laboratory the case was taken for examination in the month of March 2015 after one year of the incident. The semen was identified by AP test and Microscopy of spermatozoa. It is already known that the presence of spermatozoa and quantity of DNA is affected by environmental conditions and cloth texture of exhibits [6]. The colour of clothe may inhibit the process of DNA amplification. But there was no semen on bodily swabs and garments as routine washing was done. The vaginal wash is not affected by inhibition as it is taken in distilled water.

\section{Selection of Sample}

\section{D.N.A. Extraction}

All the samples of this case received in the lab were subjected to identification of semen by acid phosphatase test and presence of spermatozoa. As there was a lot of delay in medical examination of the victim semen could not be traced from the undergarments of the victims and different body swabs except the washing from the vagina. Even then vaginal cervical, culture and rectal swabs and underwear along with washing from vagina were taken for organic extraction [7]. The sample was in liquid form it was taken into micro centrifuge tube capacity $1.5 \mathrm{ml}$ than centrifuged at $10000 \mathrm{rpm}$. The supernatant was removed and there was only solid material left including the vaginal epithelial cells and spermatozoa as male part while other swabs were taken directly. All samples were added $500 \mu \mathrm{l}$ forensic buffer $40 \mu \mathrm{l}$ sodium dodecyl sulphate, $10 \mu \mathrm{l}$ Proteinase $\mathrm{K}$ and $10 \mu \mathrm{l}$ ditheothreitol to digest the cells. To remove the protein material and contaminants samples were added to phenol chloroform and iso amyl alcohol in the ratio of 25:24:1. Sample was precipitated with sodium acetate and isopropanol and washed with the alcohol. The purpose of this method was to extract the DNA from spermatozoa along with the epithelial cells of the victim. One of the advantages of analysis of vaginal wash that there is no other material except the distilled water in washing is taken. The inhibitors are major problem in PCR analysis in the samples like jeans pant or any other garments. Inhibitors are generally exerting their effects by interaction with DNA. A number of methods have been developed to improve PCR amplification in the presence of inhibition [8]. One of the important methods is the use of silica-based column which is generally available commonly provided by the firm like Qiagen. Three main processes include (i) binding of the inhibitor to the polymerase (ii) interaction of the inhibitor with the DNA; and (iii) interaction with the polymerase during primer extension $[9,10]$. Though during RT-PCR it has shown there was no inhibition in the vaginal washing.

\section{Quantification of DNA}

Concentration of male DNA isolated from each sample was measured by quantification method by using Quantifier Duo Kit (Applied Bio system) on the Real-Time 7500 PCR instrument [11]. This kit contains the three components Taq Man Human male specific sex determining region $\mathrm{Y}$ and Internal positive control. This technique is helpful to ascertain the quantity of male DNA in the sample and further to know the inhibition in the sample. Quantitation standards were used to quantify the DNA samples. STR gives more information and easy to use in forensic cases. In the case of autosomal STR fail to detect some markers or peaks are poor comparative to female fraction peaks than it necessary to go for Y-STR [12]. Y-STR will be done if the presence of male DNA confirmed after quantitation in RT-PCR and quantity of male is very less than human DNA due the high amount of female fraction.

\section{Results and Discussion}

The detection of semen and further DNA profiling of DNA from only one source vaginal wash become important while other 
sample failed to detect semen from the other body swabs and isolate the male DNA in sexual assault cases. Profile of accused was established and matched with one sample which is washing of vagina of the victim. Hence it could be stated that in cases of delayed medical examination of sexual assault victim vaginal washing is capable of generating positive results either by autosomal STR or Y- STR even up to four and a half days while other bodily swabs failed to detect the male DNA. Semen detection and DNA fingerprinting in sexual assault cases (included delayed medical examination) had concluded that of all the samples collected vaginal washing had a relative percentage of male DNA of $17.18 \%$ which was the highest [13] (Figure 1 and 2).
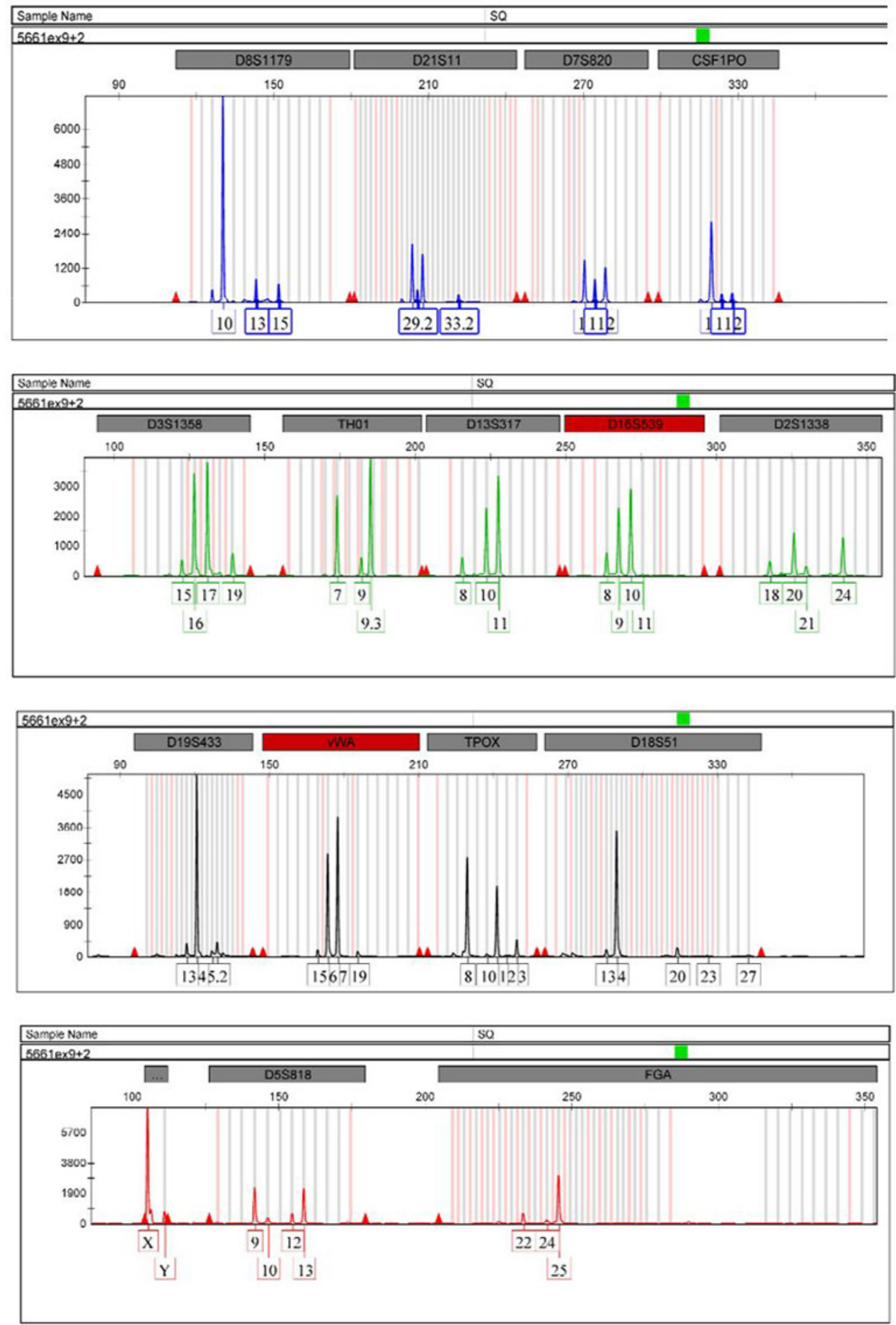

Figure 1: A mix Profile (male and female) in Autosomal STR by using identifier plus kit having 16 markers showing the low peak so female, due to low quantity of male DNA and high peaks belong to the female. 

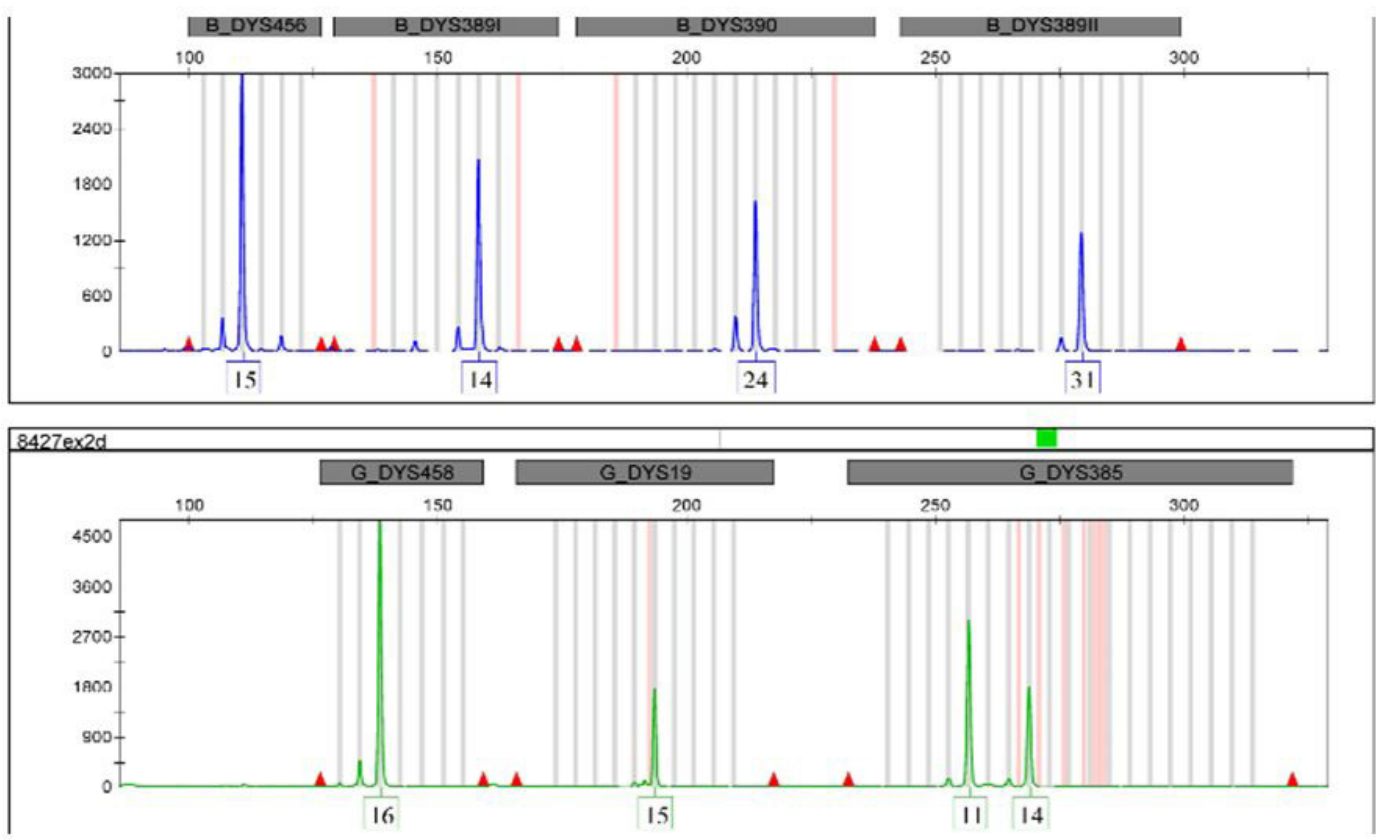

Figure 2: Profile of Y STR in sexual assault case (based on the analysis of Y chromosome specific marker) is able to eliminate the female DNA as shown in previous profile.

\section{References}

1. Green W SPJG (2003) Sexual assault and semen persistence. Encyclopedia of Forensic Science 1016-18.

2. Lewis J, Baird A, McAlister C, Siemieniuk A, Blackmore L et al (2013) Improved detection of semen by use of Acid Phosphatase testing. Sci Justice 53:385-94.

3. President DNA Initiative (2013) a national protocol for sexual assault medical forensic examination: adult/adolescents. September 2004.

4. Smith DW, Letourneau EJ, Saunders BE, Kilpatrick DG et al (2008) Delay in the disclosure of childhood rape: result from the national survey. Child Abuse Negl 24: 273-87.

5. Hilton J,Kobus,D.Phil,Edmund Silenieks,Jordana Scharnberg (2002) Improving the effectiveness of fluorescence for detection of semen stains on fabrics. J Forensic Sci 47: 289-96.

6. Seah L, Izuan Othman M, Jaya P, Jeevan HN (2004) DNA profiling on fabrics: a situ method. International Congress Series 1261:565-67.

7. Rudin N, Inman K (2001) An Introduction to Forensic DNA analysis. Second edition.

8. Bourke MT, Scherczinger CA, Ladd C, Lee HC (1999) NaOH treatment to neutralize inhibitors of tag polymerase. J Forensic Sci 44:1046-50.

9. John M B (2005) Fundamental of Forensic DNA Typing 2nd edition.

10. Moreira D (1998) efficient removal of PCR inhibitors using agarose-embedded DNA preparations. Nucleic Acids Res 26:3309-10.

11. Nicklas JA, Buel E (2003) Development of an Alu-based, real-time PCR methods for quantitation human DNA in forensic samples. J Forensic Sci 48:936-44.

12. Martin P, Albarran C,Gracia O, Gracia p, Sancho M et al (2000) Application of Y-STR analysis to rapes that cannot be solved by autosomal STR. Progress in Forensic Genetics 526-8.

13. Naresh K, Vinita G, Vijayshree S, Shukl SK (2015) Studies of different clue materials for semen detection and DNA fingerprinting in sexual assault cases. International journal of multidisciplinary Research and Development 2:286-88.

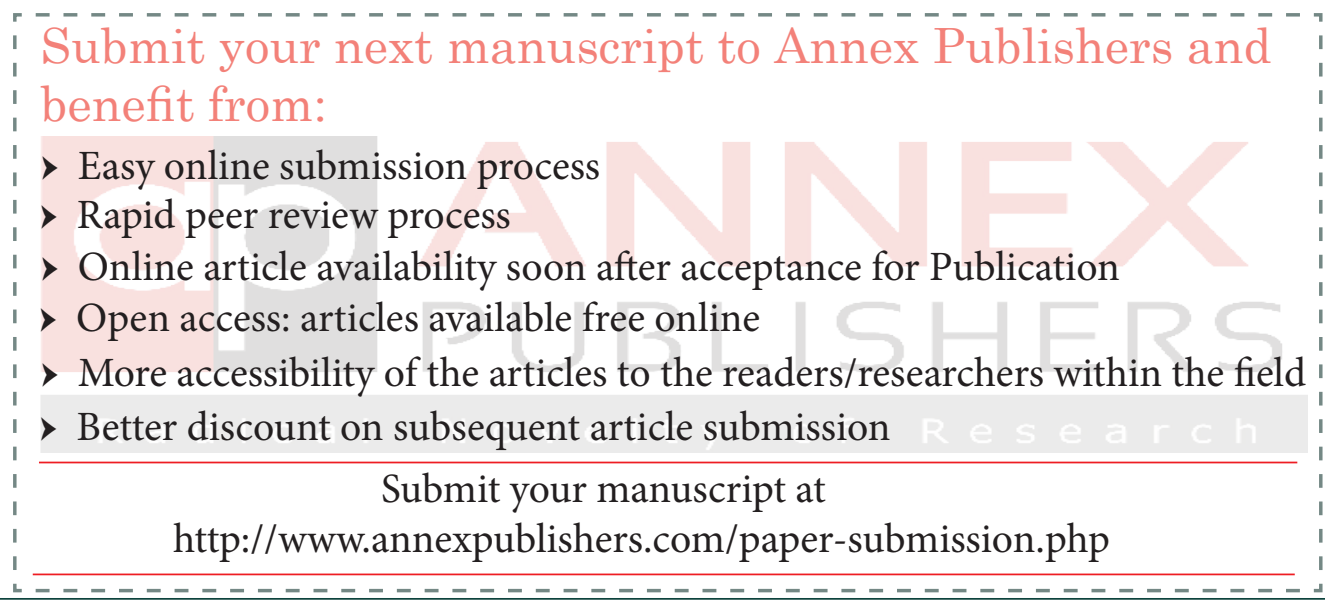

